\title{
МАТЕРІАЛОЗНАВСТВО
}

УДК 669.017

DOI: 10.30977/BUL.2219-5548.2020.88.1.7

\section{IMPROVING WEAR RESISTANCE OF RESPONSIBLE HYDRAULIC HAMMER DETAILS WITH ION-PLASMA TREATMENT}

\author{
Glushkova D. B., Ryzhkov Yu. V., Kostina L. L., \\ Chigrin A. A., Stepanyuk A. I. \\ Kharkiv National Automobile and Highway University
}

\begin{abstract}
Details of the hammer during operation are subject to wear, which leads to a decrease in their service life. In accordance with the literature data in the practice of engineering uses many methods of hardening, which do not give a significant effect. Therefore, the application of new methods of surface hardening has become topical. These methods include ion-plasma chromium plating. On the basis of experimental studies, the effect of ion-plasma chromium plating on the wear resistance and mechanical properties of hydraulic hammer parts has been established, structural changes in the material have been analyzed. Ion-plasma chromizing of the parts promotes the increase of their wear resistance in 1.75 times as compared to those which are not strengthened. The technology of ionplasma chromizing secures the running of the strengthened parts without breaking off and chipping. The zones of structural changes are marked on the sections of parts damages, which are typical for the effects of the second hardening.
\end{abstract}

Key words: ion-plasma chromium plating, hydraulic hammer, wear resistance.

\section{Problem statement}

The development of modern equipment imposes ever increasing requirements for the performance of the hydraulic hammer parts. Wear resistance issue holds a specific place in the range of problems as for the increase of their reliability and service life. Insufficient wear resistance limits the growth of hydraulic hammers efficiency and their operating life, increases the expenses for the repair and the spare parts.

More often the new methods of surface strengthening, in particular ion-plasma methods of coating, are implemented in order to increase the operational characteristics of the materials.

\section{Publication analysis}

The publication states that numerous methods are used to increase the wear resistance of equipment work surface, but they all do not provide significant increase of wear resistance [1-3]. Therefore, it was viable to implement ionplasma technologies, which are directed to increase wear resistance of the parts work surface running in the conditions of cutting wear. The parts of hydraulic hammer belong to such objects.

\section{Goals and objectives}

To determine the effect of ion-plasma chromizing on the wear-resistance of hydraulic hammer parts on the basis of experimental research.

\section{Statement of the information}

The test results of the parts, strengthened by means of ion-plasma chromizing, showed that before the coating damage, satisfactory wear resistance of the strengthened parts is observed. Therefore, the choice of modes of ion-plasma chromizing allowing to increase wear resistance of the critical hydraulic hammer parts is currently important.

The strengthening treatment (ion-plasma chromizing) under advanced technology which excludes superheat of the parts in the coating process and its chipping under the test is conducted.

The high quality coatings from fine metals are obtained under the temperatures not less than $80-100{ }^{\circ} \mathrm{C}$. The initial process materials for vacuum ion-plasma sputtering are cathodes from sputtering materials, chrome (BX-1) in this case.

A unit for ion-plasma sputtering «Bulat» was used (fig. 1). It consists of a chamber, a vacuum pumping system, a vapor source, a rotator, a water handling and a seat.

The thickness of chromium plate made 50-60 $\mu \mathrm{m}$. The roughness parameter of the strengthened surfaces $-R_{a} 0,8-3,6$. The roughness of the work surfaces after finishing reached within the limits $R_{a} 0,4-0,8$. 


\section{Wear of parts}

The degree of damage to parts strengthened by means of ion-plasma chromizing using advanced technology is shown on Fig. 2. The initial signs of the coating damage in the form of scoring marks and tearings were detected at the peak in the zones $\langle\mathrm{M}\rangle$ and $\langle\mathrm{F}\rangle$ ) after 300 loading cycles, on the hammer head in the same zones after 450 cycles.

The scratch marks in the channel cavity of the bush appeared after 600 cycles, of the case after 700 loading cycles. Flaws along the axis of the parts were formed in the channels of the case and the bush (zone $\langle\mathrm{B} »)$ and their cut after 800 cycles. Due to the coating wear of the most loaded sections of the parts the test was stopped after 1730 cycles.

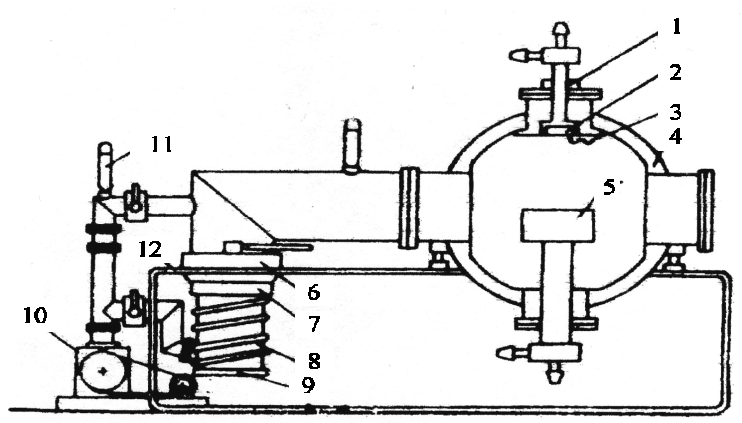

Fig. 1. General arrangement drawing of unit «Bulat»: 1 - focusing coil; 2 - cathode; 3 ignitor electrode; 4 - anode chamber; 5 - supporter; 6 - liquid nitrogen trap; 7 - water trap; 8 - high-vacuum device; 9 - heater; $10-$ backing pump; 11 - manometric lamp; 12 unit water cool system

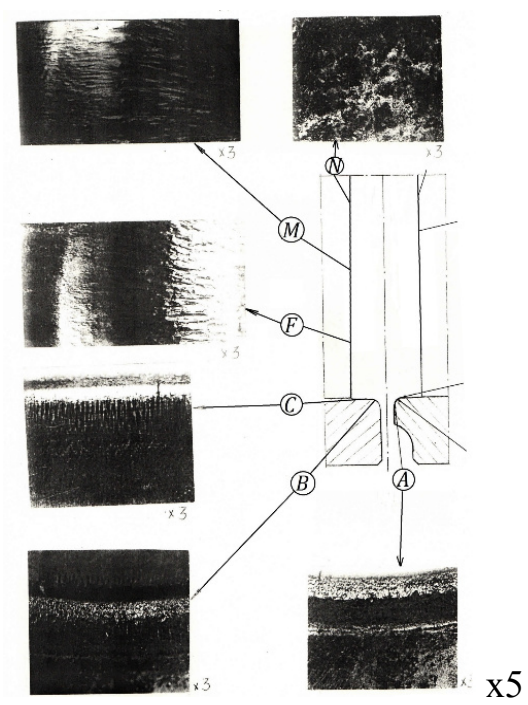

Fig. 2. Wear of the peak and the bush strengthened by means if ion-plasma chromizing (using advanced technology) x5
The measurements of the worn parts show that the equivalent diameter of the case and the bush channels in the cut zone increased to 125.5 $\mathrm{mm}$. The hammer head is worn in the zone $\langle\mathrm{N} »$ to $0.2 \mathrm{~mm}$, in the zone $\langle\mathrm{M} »$ to $0.5 \mathrm{~mm}$. Correspondingly the peak - to $0.3 \mathrm{~mm}$ and $0.85 \mathrm{~mm}$. The locations of the greatest wear zones and the nature of the damage to the parts are similar to those observed on the parts examined above.

Wear, wear hardening and metal plastic working are observed in the zone "A» of the hammer head channel (the case) and the bush (fig. 3). These effects are more intensive on the bush. The wear, surface coating plastic working and the formation of valley-tearing are seen in the zone «B». The valley tops are smoothed, worn (to the base on some sections) on the bush, the valleys are rough, without wear features on the case. Even wear, wear hardening and surface coating scaling are observed in the zone $\langle\mathrm{B}\rangle$. The scaling on the case is major, on the bus is in the initial stage of the development. The small sections of remained strengthened layer are recognized on the case. The surfaces of zone «D» are characterized with artificial aging and scaling of the material. Coating wear on the case and the bush goes without signs of chipping or peeling.

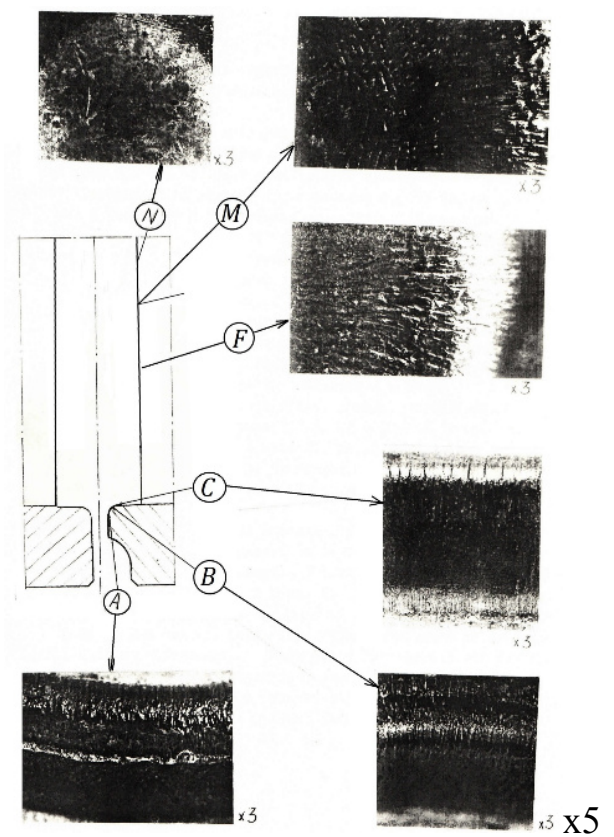

Fig. 3. Wear of the case and the hammer head, strengthened by means of ion-plasma chromizing (using advanced technology) x5

The damage nature of the hammer head and the peak is identical to the observed one on the parts tested earlier, strengthened by means of ion-plasma chromizing using initial technology. 
Smoothed spot is detected in the central section of the hammed head (zone $\langle N »)$. The coating is less worn on the hammer head, than on the peak. There is a pattern of valley-tearing developed more on the peak in the zone $\langle\mathrm{M} »$.

The pattern of valleys on the hammer head is significantly smoothed in the result of the wear. It is specified that the hammer head and the peak differ less as for the extent of valleys development than the hammer head and the peak of the strengthening variants tested earlier. Zone $\langle\mathrm{F}\rangle$ is characterized with coating wear, wear hardening and smooth surface. The damage in this zone is even on the circle of the parts and practically identical on the hammer head and the peak.

The marks of artificial aging and wear hardening of the coating are observed in the zone «E». Galling to the arris of cylindrical surface is specified on the edges of the parts.

Flaws are observed on the tested parts of the examined variant (fig. 4 and 5).

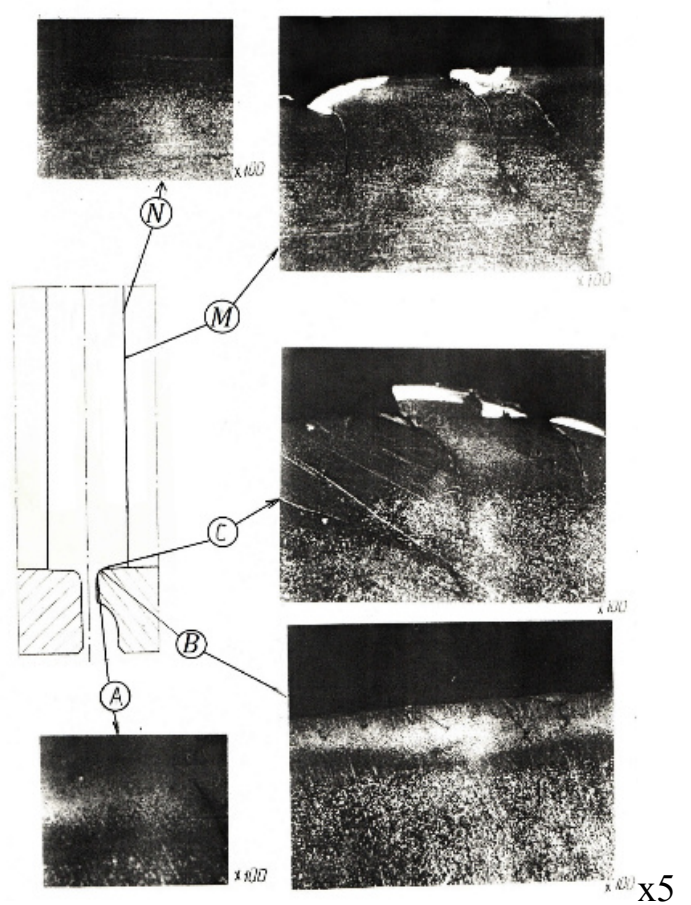

Fig. 4. Structural changes of the material of the case and the hammer head strengthened by means of ion-plasma chromizing (using advanced technology) $\mathrm{x} 5$

Flaws on the case and the bush are observed in the zones «A» and «B». Their depth on the case reaches $0.55 \mathrm{~mm}$, on the bush $0.4 \mathrm{~mm}$. There are no flaws in the zones $\langle\mathrm{C} »$ and $\langle\mathrm{D}\rangle$. Flaws on the hammer head are found in the zone $« \mathrm{~N} »$ of 0.3 $\mathrm{mm}$ depth and in the zone «M» - up to $0.6 \mathrm{~mm}$. There are flaws on the peak only in the zone «M» of 0.6 depth.

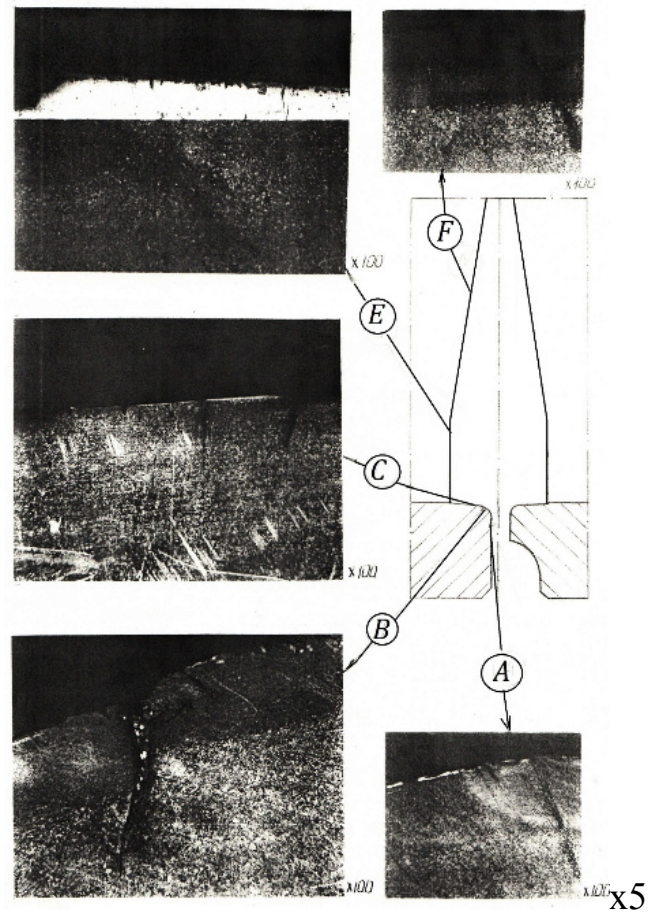

Fig. 5. Structural changes of the material of the peak and the bush strengthened by means of ion-plasma chromizing (using advanced technology) x5

Appearance of the flaws in the fractures is identical to the earlier observed on the other variants of strengthening (outlined contour, burning and smoothed surface).

On the case and the bush, the remains of the coating are observed in the zones $\langle A\rangle$ and $\langle\mathrm{C} »$, the wear is insignificant in the zone «D».

The depth of the remained coating on the bush in the zones $\langle\mathrm{A} »$ and $\langle\mathrm{C}\rangle$ is $10 \mu \mathrm{m}$, in the zone $\langle\mathrm{D} »-40 \mu \mathrm{m}$, on the case (channel) in the zone $\langle\mathrm{C}$ » up to $10 \mu \mathrm{m}$, in the zone $\langle\mathrm{D} »-20-30$ $\mu \mathrm{m}$. The coating remained only in the zones «N» and «E» on the hammer head and the peak. The thickness of the layer on the hammer head is $10 \mu \mathrm{m}$, on the peak - up to $5 \mu \mathrm{m}$.

The structural changes are observed in the metal of the examined parts in the damage areas. The structural changes for the depth $0.25-0.30$ $\mathrm{mm}$ on the bush are indicated in the zones «A» and $« B »$. The hardness of material in the structural changes zones is HV510-645.

The structural changes for the depth 0.25 $0.30 \mathrm{~mm}$ are observed in the zones «N» and «M» on the peak material. On the hammer head in the same zones the depth of the structural changes is $0.15-0.20 \mathrm{~mm}$. The hardness of material in the structural changes zones is HV510-585. 
The hardness of the material of the examined parts: the bush - HRC40-42; the peak HRC40-42; the case - HRC40-42; hammer head - HRC $40-42$.
The material microstructure of the parts is of sorbit type, with finely dispersed structure. The test results of the mechanical characteristics of the parts material for stretching is presented in the table 1 .

Table 1 - Mechanical characteristics of the parts material, strengthened by means of ion-plasma chromizing (using advanced technology)

\begin{tabular}{|c|c|c|c|c|c|}
\hline \multirow{2}{*}{ Part name } & $\begin{array}{c}\text { Direction of samples } \\
\text { cut }\end{array}$ & \multicolumn{4}{|c|}{ Mechanical characteristics } \\
\cline { 2 - 6 } & axial & $1,390,0-1,430,0$ & $1,310,0-1,360,0$ & 8.0 & 23.0 \\
\hline \multirow{2}{*}{$\begin{array}{c}\text { Hammer } \\
\text { head }\end{array}$} & tangental & $1,490,0$ & $1,400,0-1,430,0$ & 15.0 & 56.0 \\
\hline \multirow{2}{*}{ Peak } & axial & $1,460,0$ & $1,380,0$ & $6.4-8.0$ & $3.0-15.0$ \\
\cline { 2 - 6 } & tangental & $1,450,0-1,510,0$ & $1,360,0-1,375,0$ & 13.0 & $51.0-54.0$ \\
\cline { 2 - 6 } & & &
\end{tabular}

\section{Conclusions}

1. The tests results of the parts strengthened by means of ion-plasma chromizing using advanced technology show that the increase of their wear resistance in 1.75 times is guaranteed comparing to the initial (which were not subjected to special strengthening).

2. The damage of the work surfaces of the tested parts is identical to the parts examined earlier as for the nature and locations of the zones.

3. The damage of the details is characterized with the coating wear, metal wear hardening, formation of valley-tearing and flaws. The strengthening coating was practically worn in the most loaded sections of parts (in the zone $\langle\mathrm{B}\rangle$ ) and $\langle\mathrm{C}\rangle$ on the hammer head case and the bush and $\langle\mathrm{M}\rangle$ and $\langle\mathrm{F}\rangle$ on the hammer head and the peak.

4. The advanced technology of ion-plasma chromizing provides the running of the strengthened parts without breaking off and chipping of the coating.

5. The feature of the tests results of this strengthening variant is lesser wear of the lower parts (the bush, the peak) as compared with upper parts.

6. On the sections of parts damage there are zones of material structural changes for the depth to $0.3 \mathrm{~mm}$, typical for secondary hardening effects.

7. There are flaws on all parts: on the case and the bush in the zones "A» and «B» up to $0.55 \mathrm{~mm}$, on the hammer head and the peak up to $0.6 \mathrm{~mm}$. No flaws are identified in the other zones of parts damage.

\section{Литература}

1. Виноградов М. И., Маншев Ю. П. Вакуумные процессы и оборудование ионно- и электрон- нолучевой технологии. Москва: Машиностроение, 2009. 56 с.

2. Гришин С. Д., Лесков Л. В., Козлов Н. П. Плазменные ускорители. Москва: Машиностроение, 2003. $174 \mathrm{c}$.

3. Пархоменко В. Д., Цыбулев П. Н., Краснокутский Ю. И. Технология плазмохимических производств. Киев: Вища школа, 2001. 255 с.

\section{References}

1. Vinogradov M. I., Manshev U. P. The vacuum processes and equipment of iono- and electron ray technology. Moskov: Machine-building, 2009. 56 p.

2. Grischin S. D., Leskov L. V., Coslav N. P. Plasma accelerators. Moskov: Machine-building, 2003. 174 p.

3. Parchomenco V. D., Chubalev P. N., Krasnokutsky U. I. The technology of plasma-chemical productions. Kiev: Vuscha chkola, 2001. 255 p.

Hlushkova D. - Doct. Sc., Chef of Department of Technology of Metals and Materials Science, tel:057-707-37-29, diana@,khadi.kharkov.ua

Ryzhkov Yu. - PhD, Associate Professor, Department of Technology of Metals and Materials Science, tel:057-707-37-92, diana@,khadi.kharkov.ua

Kostina L.L. - PhD, Associate Professor, Department of Technology of Metals and Materials Science, tel: 057-707-37-92, kostina4991@gmail.com

Chigrin A. - Assistant Department of Technology of Metals and Materials Science, tel:

057-707-37-92, diana@khadi.kharkov.ua

Stepanyuk A. - Assistant Department of Technology of Metals and Materials Science, tel:057-707-37-92, Dioxid26@meta.ua

Kharkiv National Automobile and Highway University, 25, Yaroslava Mudrogo str., Kharkiv, 61002, Ukraine. 
Підвищення зносостійкості відповідальних деталей гідромолота іонно-плазмовим обробленням

Анотація. Деталі гідромолота в процесі експлуатаиіï піддаються зношуванню, щзо призводить до зменшення строку їх роботи. Відповідно до наукових даних у практииі машинобудування використовується багато методів змічнення, які не дають суттєвого ефекту. Тому актуальним $\epsilon$ питання застосування нових методів поверхневого зміцнення. До таких методів належить іонноплазмове хромування. На основі експериментальних досліджень встановлено вплив іонноплазмового хромування на зносостійкість і механічні властивості деталей гідромолота та проаналізовані структурні зміни в матеріалі. Іонноплазмове хромування деталей сприяє підвищенню їх зносостійкості в 1,75 раза, як порівняти з тими, шуо не підлягали зміцненню. Технологія іонноплазмового хромування забезпечує роботу змічнених деталей без сколів та без викрошування. На ділянках пошкодження деталей $\epsilon$ зони структурних перетворень, характерні для явищ вторинного гартування.

Ключові слова: іонно-плазмове хромування, гідромолот, опір зношуванню.

Глушкова Діана Борисівна - д.т.н., завідувач кафедри технології металів та матеріалознавства, тел.: 057-707-37-29, diana@khadi.kharkov.ua Рижков Юрій Володимирович - к.т.н.. доцент кафедри технології металів та матеріалознавства, тел.: 057-707-37-92, diana@khadi.kharkov.ua Костіна Людмила Леонідівна - к.т.н., доцент кафедри технології металів та матеріалознавства, тел.: 057-707-37-92, kostina4991@gmail.com

Чигрин Анатолій Олександрович - асистент кафедри технології металів та матеріалознавства, тел.: 057-707-37-92, diana@,khadi.kharkov.ua Степанюк Андрій Іванович - асистент кафедри технології металів та матеріалознавства, тел.: 057-707-37-92, Dioxid26@meta.ua, Харківський національний автомобільнодорожній університет, 25, вул. Ярослава Мудрого, м. Харків, 61002, Україна.

Повышение износостойкости ответственных деталей гидромолота ионно-плазменной обработкой
Аннотация. Детали гидромолота в процессе эксплуатации подвергаются износу, что приводит к уменьшению срока их службы. В соответствии с данными научной литературы в практике машиностроения используется значительное количество методов упрочнения, которые не дают существенного эффекта. Поэтому стало актуальным применение новых методов поверхностного упрочнения. К таким методам относится ионно-плазменное хромирование. На основании экспериментальных исследований установлено влияние ионноплазменного хромирования на износостойкость $u$ механические свойства деталей гидромолота $u$ проанализированы структурные изменения в материале. Выявлены особенности изнашивания деталей гидромолота по длине и в разичных участках сечения. На участках повреждения деталей отмечаются зоны структурных превращений, характернье для явлений вторичной закалки. Ионно-плазменное хромирование деталей способствует повышению их износостойкости в 1,75 раза по сравнению с неупрочненными. Технология ионно-плазменного хромирования обеспечивает работу упрочненных деталей без сколов и без выкрашивания.

Ключевые слова: ионно-плазменное хромирование, гидромолот, сопротивление износу.

Глушкова Диана Борисовна - д.т.н., заведующий кафедры технологии металлов и материаловедения, тел.: 057-707-37-29,

diana@khadi.kharkov.ua

Рыжков Юрий Владимирович - к.т.н., доцент кафедры технологии металлов и материаловедения,

тел.: 057-707-37-92, diana@khadi.kharkov.ua

Костина Людмила Леонидовна - к.т.н., доцент кафедры технологии металлов и материаловедения, тел.: 057-707-37-92, kostina4991@gmail.com Чигрин Анатолий Александрович - ассистент кафедры технологии металлов и материаловедения, тел.: 057-707-37-92, diana@khadi.kharkov.ua Степанюк Андрей Иванович - ассистент кафедры технологии металлов и материаловедения, тел.: 057-707-37-92, Dioxid26@,meta.ua,

Харьковский национальный автомобильнодорожный университет, 25, ул. Ярослава Мудрого, г. Харьков, 61002, Украина. 